\title{
Regression Analysis of Strong El-Nino and La-Nina Periode to Groundwater Availability in Palembang City
}

\author{
Rezfiko Agdialta ${ }^{12^{*}}$ \\ ${ }^{1}$ Palembang Climatology Station \\ ${ }^{2}$ Indonesian Agency for Meteorology Climatology and Geophysics \\ *Corresponding Author: rezfikoagdialta@gmail.com
}

\begin{tabular}{llll} 
Article history & & \\
\hline Received & Received in revised form & Accepted & Available online \\
05 May 2019 & 1 August 2019 & 30 August 2019 & 31 August 2019 \\
\hline
\end{tabular}

\begin{abstract}
El-Nino results in reduced air mass in most parts of Indonesia and can cause drought. In the La-Nina phase some parts of Indonesia will get more water vapor resulting in increased frequency of rain. Increased rainfall has an impact on groundwater availability. Groundwater availability illustrates the condition of water in the soil which is useful in many sectors of life, especially in the agricultural sector. This study aims to see the relationship between the El Nino and La Nina phenomena strongly by using SOI indicators on groundwater availability in Palembang. In the Strong El-Nino phase in 1994 and 1997 the SOI variable had a weak correlation with groundwater availability variable of 0.32 and 0.39 . In 2015 the correlation of SOI variable to groundwater avability was 0.79 indicating a strong corellation. In 2008 and 2011 which was a strong La-Nina phase the SOI index correlation value for groundwater availability was 0.46 and 0.45 , respectively, which indicated a moderate correlation.
\end{abstract}

Keywords: El-Nino, Groundwater Availability, La-Nina, Palembang, Thronthwaite-matter

Abstrak (Indonesian): El-Nino mengakibatkan berkurangnya massa udara di sebagian besar wilayah Indonesia dan dapat mengakibatkan kekeringan. Pada fase La-Nina sebagian wilayah Indonesia akan mendapatkan lebih banyak uap air sehingga mengakibatkan meningkatnya frekuensi hujan. Peningkatan curah hujan berdampak kepada air tanah tersedia. Air tanah tersedia menggambarkan kondisi air di dalam tanah yang berguna dalam banyak sektor kehidupan terutama pada sektor pertanian. Penelitian ini bertujuan untuk melihat hubungan antara fenomena El Nino dan La Nina kuat dengan mengunakan indikator SOI terhadap air tanah tersedia di kota Palembang. Pada fase El-Nino Kuat tahun 1994 dan 1997 variable indeks SOI memiliki korelasi yang lemah terhadap variable air tanah tersedia sebesar 0.32 dan 0.39. Tahun 2015 korelasi SOI terhadap air tanah tersedia sebesar 0.79 menunjukkan korelasi yang kuat. Tahun 2008 dan 2011 yang merupakan fase La-Nina kuat nilai korelasi indeks SOI terhadap air tanah tersedia berturut-turut sebesar 0.46 dan 0.45 yang menunjukkan adanya korelasi sedang.

Kata kunci: Air Tanah Tersedia, El-Nino, La-Nina, Palembang, Thronthwaite-Mather

\section{Introduction}

The El-Nino and La-Nina phenomena that occurred in the past few years became one of the events that received very important attention from the community, researchers, and also the government. Some regions in Indonesia at El-Nino was in droughts, meanwhile at La Nina was in flood. In Indonesia, the El-Nino phenomenon is often associated with forest and land fires that cause smoke haze, especially those that occur on the island of Borneo [1].

El-Nino and La-Nina consist of three phases, namely the El-Nino, La Nina, and neutral phases. ElNino comes from Spanish which means boy. The term was first used by fishermen in Peru and Ecuador in the 19th century to refer to a period of warmer oceans that affected the decline in the number of fish catches they got [2]. According to WMO (2014),
ENSO (El-Nino Southern Oscillation) is a phenomenon that occurs due to fluctuations in sea surface temperatures in the eastern Pacific region that affect climate patterns in Indonesia and other regions of the world. A better understanding of ENSO in the future can be used to help the community and government in dealing with possible disasters caused by this event.

One method used to determine the incidence of El-Nino and La-Nina is to look at changes in the value of the SOI (Southern Oscillation Index). SOI is an index that shows changes or fluctuations in pressure that occur in the west and east of the Pacific region during the period of the El-Nino and La-Nina events [3]. The calculation of the SOI value uses the Troup method developed by the Beraue of Meteorology (BOM) Australia by calculating the 
standard difference in the average sea surface temperature anomaly between Darwin and Tahiti.

The results of these calculations then be divided into several ranges of classes which can be used as part of the reference for the El-Nino and La-Nina periods as follows:

Table 1. Reference to SOI Values Determination of El-Nino and La-Nina

\begin{tabular}{cc}
\hline SOI Value & Information \\
\hline $\begin{array}{c}\text { Under }-10 \text { for } 6 \text { months } \\
\text { months }\end{array}$ & Strong El-Nino \\
\hline $\begin{array}{c}\text { Between }-5 \text { to }+5 \text { for } 6 \\
\text { months }\end{array}$ & Weak El-Nino \\
\hline $\begin{array}{c}\text { Between }+5 \text { to }+10 \text { for } 6 \\
\text { months }\end{array}$ & Weak La-Nina \\
\hline Above +10 for 6 months & Strong La-Nina \\
\hline $\begin{array}{l}\text { Source : Australia Government Bureau of Meteorology } \\
\end{array}$
\end{tabular}

Water is the most important basic component that exists on the surface of this earth. In the hydrological cycle of groundwater provides a considerable role in the availability of water. According to [4], groundwater is a natural resource that can be updated but this does not mean that groundwater can be exploited indefinitely. Based on the hydrological cycle of water that enters the soil and is absorbed and stored in the soil due to rain. In the rainy season, the capacity of groundwater can be in a stable state, but during the dry season, the amount of groundwater availability will also be depleted. Therefore, this study aims to see the extent to which the El-Nino and La-Nina phenomena in a strong period of influence on groundwater availability in Palembang City.

\section{Material and Methods}

\subsection{Data Collection}

The initial stage of this research is the data collection stage. The data used in this study are secondary data in the form of monthly SOI index data for the last 30 years, namely the period $1989-2018$ obtained from http://www.bom.gov.au which is then used to calculate and analyze the year with the event El-Nino and La-Nina are strong during that time span. In addition, this study uses secondary data in the form of rainfall and temperature data obtained from the Palembang BMKG Climatology Station. The rainfall and temperature data are then processed using the Thornwaite-matter land water balance method to obtain the value of groundwater availability in the city of Palembang for the past 30 years.

\subsection{Calculating Evapotranspiration (ETP) Value}

Temperature data is used to obtain the evapotranspiration (ETP) value using the PenmanMonteith calculation method [5]. Then the results of processing will produce groundwater availability data output which will then be analyzed using a simple regression method on SOI values, and will be further analyzed using Pearson correlation method to see how far fluctuations in SOI values affect groundwater availability in the city of Palembang during the El period -Nino and La-Nina are strong.

\subsection{Calculating Groundwater Availability Value}

To calculate the value of groundwater availability is using the Thronthwaite-Mather [6] method through several stages as follows:

1. Input monthly rainfall data from the location to be analyzed;

2. Calculating the value of the evapotranspiration that would happen if there is an enough moisture supply at all times with other conditions satisfied, Potential Evapotranspiration (ETP) [7].

3. Calculating the difference between Rainfall and Evapotranspiration (AT);

4. Calculating the accumulated value of potential water losses for evaporation (APWL);

5. Calculate the value of soil moisture content (SMC) with the following formula:

$$
\mathrm{SMC}=+[[1,00041-(1.07381 / \mathrm{AT})]|\mathrm{APWL}| \mathrm{xAT}
$$

Notes:

PWP is a permanent wilting point, permanent wilitng point is explained as the volumetic water content in the lowest level that can be achieved by plant transpiration [8];

FC is field capacity, field capacity is defined as the water that is remaining in a vertical soil column subject to $1 / 3$ atm [9]. 
Table 2. Value of Field Capacity (KL) and Permanent Wading Point (WP)

\begin{tabular}{ccccc}
\hline No & Province & City & $\begin{array}{c}\text { FC } \\
(\mathrm{mm})\end{array}$ & $\begin{array}{c}\text { WP } \\
(\mathrm{mm})\end{array}$ \\
\hline 1 & South Sumatera & Palembang & 300 & 150 \\
\hline
\end{tabular}

Source: [9].

6. Calculating the dSMC value, the dSMC value is calculated by subtracting the SMC of the month to be analyzed by the SMC value in the previous month;

7. Calculating the value of Actual Evapotranspiration (ETA). If Rainfall is greater than ETP, then ETA reaches the maximum value. If Rainfall is smaller than the ETP value, the ETA value is obtained from the sum of rainfall and dSMC, where dSMC is absolute because all rainfall and dSMC will be evapotransposed;

8. Calculating the value of the deficit obtained from the difference in Potential Evapotranspiration (ETP) with Actual Evapotranspiration;

9. Calculating the surplus value which is an excess of groundwater which generally occurs in the rainy season. For the calculation of surplus is to use the formula $S$ = Rainfall - ETP - dSMC;

10.Calculate the value of groundwater availability (GWA) with the following equation:

$\mathrm{GWA}=((\mathrm{SMC}-\mathrm{PWP}) /(\mathrm{FC}-\mathrm{PWP})) / 100 \%$

Notes:
GWA is groundwater availability. PWP is a permanent wilting point. FC is field capacity.

Thronthwaite-Mather method divides the value of groundwater availability into several categories, including the following:

Table 3. Percentage of Groundwater Availability

\begin{tabular}{ccc}
\hline No & $\begin{array}{c}\text { Groundwater } \\
\text { Availability }\end{array}$ & Percentage \\
\hline 1 & Very Less & $<10 \%$ \\
2 & Less & $10-40 \%$ \\
3 & Medium & $40-60 \%$ \\
4 & Enough & $60-90 \%$ \\
5 & Very Enough & $90 \%$ \\
\hline
\end{tabular}

Source: Thronthwaite-Mather Method

\section{Results and Discussion}

Based on SOI data for the last 30 years in the period 1989 - 2018 the monthly average values have been obtained as follows:

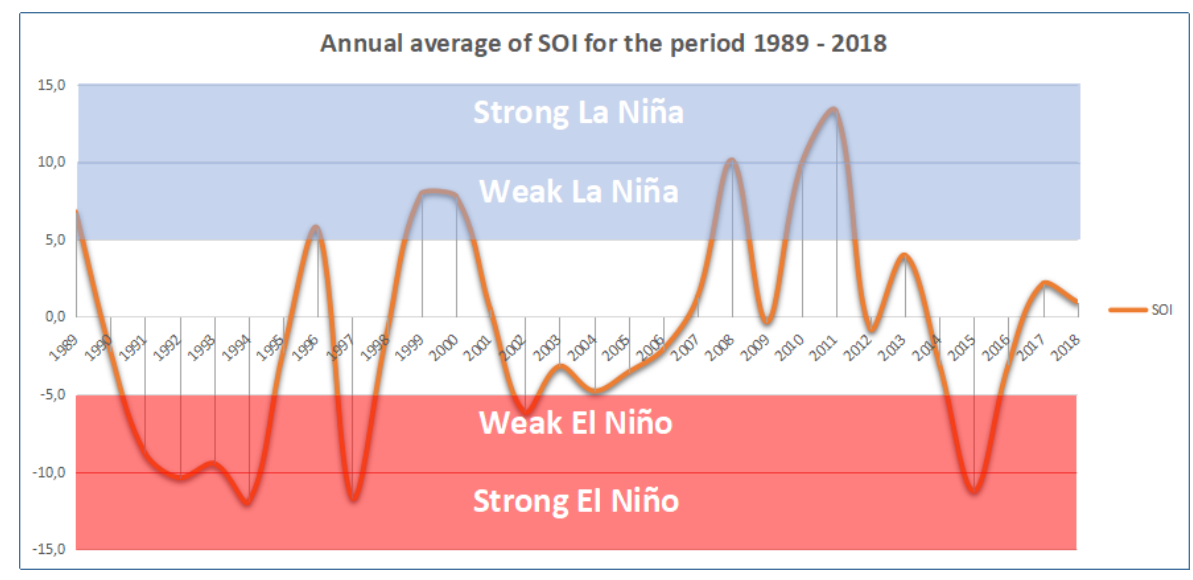

Figure 1. Annual average of SOI for the period $1989-2018$

From the index value above, it can be concluded that the periods of El-Nino and La-Nina are characterized by SOI values which are below -5.0 for El-Nino and above +5.0 which indicate the LaNina event occurred in 1989, 1996, 1999, 2000, 2008, 2010, 2011 for the La-Nina event and El-Nino year occurred in 1992, 1994, 1997, 2015. Based on the provisions of Australia the Government of Beraue of Meteorology El-Nino is of strong value if the SOI index is below -10 and occurs for 6 months consecutive. Strong La-Nina events occur if the SOI index value is above +10 for 6 consecutive months. From the graph above, it can be concluded that the strong El-Nino events occurred in the periods of 1994, 1997 and 2015. Meanwhile, the La-Nina period was strong in 2008 and 2010. This needs to be strengthened whether the SOI index value is above that year -10 and +10 for 6 consecutive months. 
Table 4. Correlation of Southern Oscilattion Index (SOI) to Groundwater Availability during the Strong El-Nino periods

\begin{tabular}{|c|c|c|c|c|c|c|}
\hline \multirow[t]{2}{*}{ Month } & \multicolumn{3}{|c|}{ Southern Oscilattion Index (SOI) } & \multicolumn{3}{|c|}{ Groundwater Availability (\%) } \\
\hline & 1994 & 1997 & 2015 & 1994 & 1997 & 2015 \\
\hline January & $-1,6$ & 4,1 & $-7,8$ & 100 & 100 & 100 \\
\hline February & 0,6 & 13,3 & 0,6 & 100 & 100 & 100 \\
\hline March & $-10,6$ & $-8,5$ & $-11,2$ & 100 & 100 & 100 \\
\hline April & $-22,8$ & $-16,2$ & $-3,8$ & 100 & 100 & 100 \\
\hline May & -13 & $-22,4$ & $-13,7$ & 61 & 100 & 99,9 \\
\hline Juny & $-10,4$ & $-24,1$ & -12 & 35 & 55,2 & 100,0 \\
\hline July & -18 & $-9,5$ & $-14,7$ & 100 & $-0,1$ & 25,0 \\
\hline August & $-17,2$ & $-19,8$ & $-19,8$ & 24 & $-39,3$ & $-22,0$ \\
\hline September & $-17,2$ & $-14,8$ & $-17,8$ & -22 & $-63,1$ & $-53,6$ \\
\hline October & $-14,1$ & $-17,8$ & $-20,2$ & -46 & $-78,2$ & $-74,0$ \\
\hline November & $-7,3$ & $-15,2$ & $-5,3$ & 100 & $-80,4$ & 100,0 \\
\hline December & $-11,6$ & $-9,1$ & $-9,1$ & 100 & 100,0 & 100,0 \\
\hline Average & $-11,9$ & $-11,7$ & $-11,2$ & 62,7 & 32,8 & 56,3 \\
\hline Corellation & & & & 0.32 & 0.39 & 0.79 \\
\hline
\end{tabular}

The annual average value of groundwater availability in the periods of 1994, 1997 and 2015 shows that during that period groundwater availability at a moderate and less-than-average level. groundwater availability was at a low level in 1997.

Table 5. Category of Correlation Coefficient

\begin{tabular}{cc} 
Correlation Coefficient & Category \\
\hline $0-0,2$ & Very Weak Correlation \\
$0,2-0,4$ & Weak Correlation \\
$0,4-0,7$ & Moderate Correlation \\
$0,7-0,9$ & Strong Correlation \\
$>0,9$ & Very Strong Correlation \\
\hline
\end{tabular}

Source: Guilford Category

During the El-Nino period, the strongest correlation value in 2015 was 0.79 . This value indicates that there is a strong relationship between the value of SOI fluctuations in groundwater availability in Palembang City. Meanwhile, in 1994 and 1997, the correlation value based on [11] correlation coefficient category was in the weak correlation with the interval between $(0.20-0.40)$, which was 0.32 and 0.39 respectively, which showed a weak correlation between SOI fluctuations variable and groundwater availability variable in Palembang

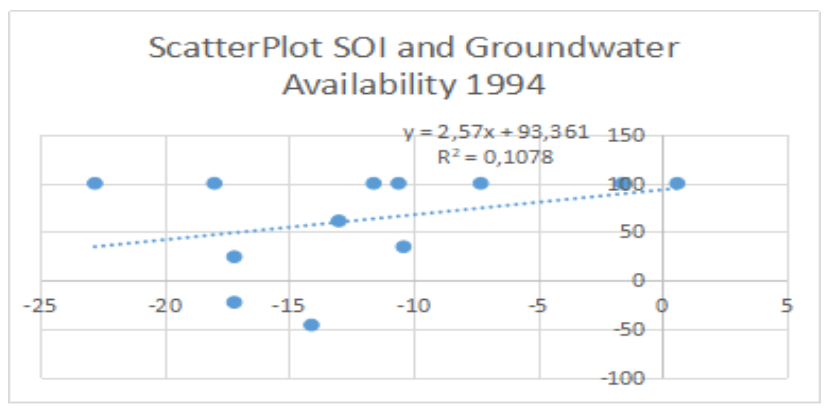

during the year period.

Figure 2. Scatterplot for SOI and Groundwater Availability 1994

The relationship of SOI index value to groundwater availability during the strong El-Nino period in 1994, 1997 and 2015 was analyzed using simple linear regression analysis using the average SOI index value in El-Nino years as a strong independent variable $(\mathrm{x})$ and groundwater availability 
is used as a dependent variable (y). The results of these calculations produce a regression equation in 1994 as shown in figure 2 which is $\mathrm{y}=93,361+$ $2,57 x$. This simple linear regression equation has a correlation coefficient $\mathrm{r}$ of 0.32 The determination coefficient of 0.1 indicates that there is only a $10 \%$ variation of SOI that affects groundwater availability.

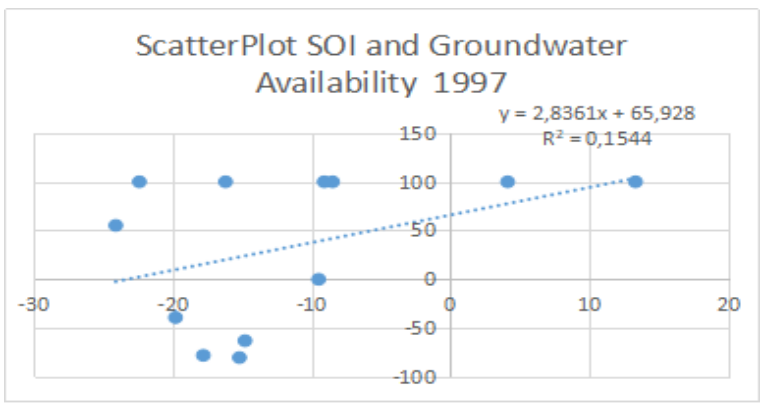

Figure 3. Scatterplot for SOI and Groundwater Availability 1997

Figure 3 shows the regression equation in 1997 which was equal to $y=65,928+2,83 x$. The coefficient of determination of 0.15 indicates that there is only a $15 \%$ variation in SOI affecting groundwater availability in Palembang. The regression equation has a correlation coefficient $r$ of 0.39. So it can be concluded that the strong El-Nino incident in 1997 affected groundwater availability in Palembang but only at a moderate level.

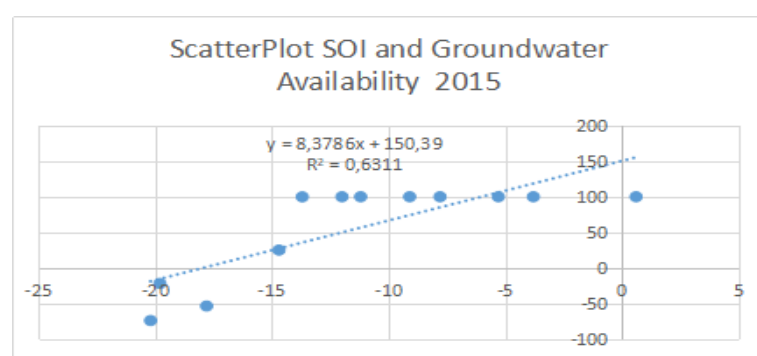

Figure 4. Scatterplot fot SOI and Groundwater Availability 2015

The regression equation in 2015 produced a value of $\mathrm{y}=150.39+8.37 \mathrm{x}$ with a correlation coefficient $\mathrm{r}$ of 0.79 indicating a strong correlation between SOI variable fluctuations in the value of groundwater availability variable in Palembang. Based on Guilford's correlation coefficient category shows that in 2015 SOI variable and groundwater availabity variable have a storong correlation. The coefficient of determination worth 0.63 indicates that there is a $63 \%$ variation of SOI affecting groundwater availability in Palembang during the strong El-Nino period in 2015. The best regression equation and correlation during the strong El-Nino year period is in 2015. The regression equation in the strong El-Nino year which has a positive value indicates that the increase in the SOI index variable is directly proportional to the increase in groundwater availability variable in Palembang and vice versa.

Table 5. Correlation of Southern Oscillation Index (SOI) to Groundwater Availability during the Strong La-Nina period

\begin{tabular}{ccccc}
\hline Month & \multicolumn{2}{c}{ Southern Oscilattion Index (SOI) } & \multicolumn{2}{c}{ Groundwater Availabilty $(\%)$} \\
\hline January & 2008 & 2011 & 2008 & 2011 \\
February & 14,1 & 19,9 & 100 & 100 \\
March & 21,3 & 22,3 & 100 & 100 \\
April & 12,2 & 21,4 & 100 & 100 \\
May & 4,5 & 25,1 & 100 & 100 \\
Juny & $-3,5$ & 2,1 & 40,4 & 100 \\
July & 4,2 & 0,2 & $-6,3$ & 49 \\
August & 2,2 & 10,7 & 100 & 1 \\
September & 9,1 & 2,1 & 100 & -34 \\
October & 13,5 & 11,7 & 48,9 & -60 \\
November & 13,4 & 7,3 & 100 & 100 \\
December & 17,1 & 13,8 & 100 & 100 \\
Average & 13,3 & 23 & 100 & 100 \\
Corellation & 10,1 & 13,3 & 81,9 & 62,9 \\
\hline
\end{tabular}

2008 and 2015 were the phases of strong LaNina. In that year based on the correlation table, it can be seen that the correlation value of the SOI index for groundwater availability in a row is 0.46 and 0.45 . The average value of groundwater availability is $81.9 \%$ and $62.9 \%$, respectively, 
indicating that the average percentage of groundwater availability in the La-Nina period is enough. Correlations that are worth more than 0.30 indicate that there is a weak correlation between the SOI index variable and groundwater availability variable in Palembang.

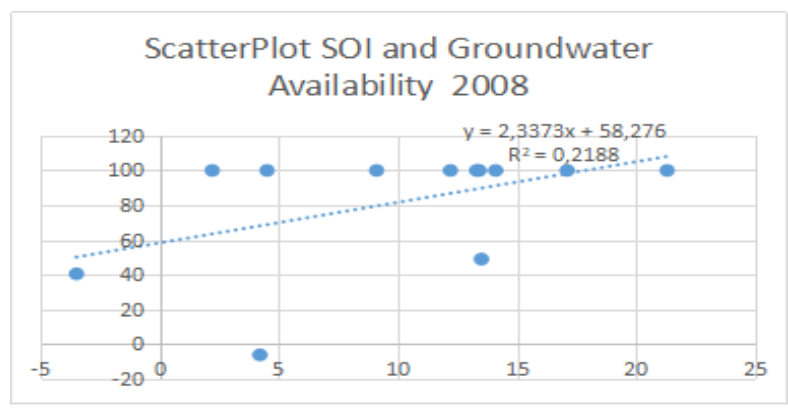

Figure 5. SOI and Groundwater Availability 2008 Scatterplot

The regression equation of the SOI and groundwater availability index values in 2008 yielded a value of $y=58,276+2,3373 x$ with a correlation coefficient $r$ of 0.46 indicating that there is a moderate relationship between SOI fluctuations in groundwater availability in Palembang. The coefficient of determination which is worth 0.21 indicates that there is $21 \%$ variation in the value of SOI that affects groundwater availability. The regression equation that has a positive value indicates that the SOI value is directly proportional to groundwater availability.

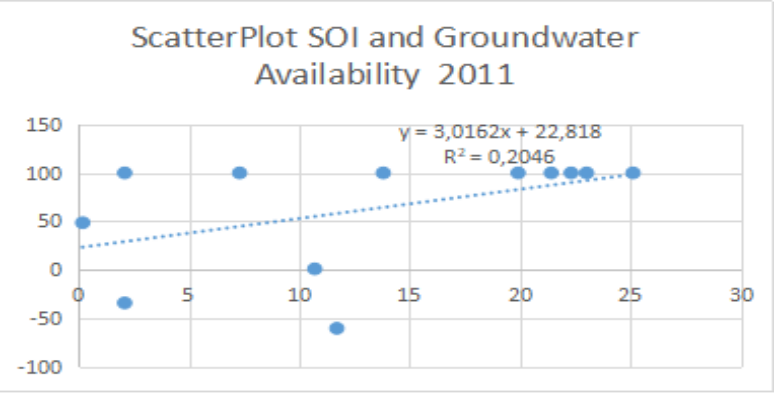

Figure 6. SOI and Groundwater Availability 2011 Scatterplot

The corellation of SOI variable to groundwater availability variable in La-Nina year has a medium value correlation. The regression equation that has a value of $y=22,818+3,0162 x$ shows that the fluctuations in the SOI value are directly proportional to changes in groundwater availability in Palembang City. The coefficient of determination $\left(\mathrm{r}^{2}\right)$ which is worth 0.20 or equal to $20 \%$ indicates that there is a $20 \%$ variation in the value of SOI that affects the value of groundwater availability. So it can be concluded that the variable of SOI in La-Nina years which is 2008 and 2011 affected changes to groundwater availability variable but it was only at a moderate level correlation.

\section{Conclusion}

From this research, conclusions can be drawn as follows:

1. During the last 30 years based on the calculation of the average of SOI value of the year included in the strong El-Nino phase, it was 1994, 1997, 2015. Beside, from the calculation of the average of SOI value of the year included in the strong La-Nina phase, it was in 2008 and 2010.

2. In the strong El-Nino year, the average groundwater availability is moderate (1994 and 2015) and less (1997).

3. In the year of strong La-Nina, the average of groundwater availability was in enough based on Thronthwaite-Mather method Percentage of Groundwater Availability .

4. The highest correlation value between SOI fluctuations variable to groundwater availability variable is in 2015 with a correlation value of $0.79 \%$ with a determination coefficient of 0.69 .

5. In the strong El-Nino years 1994 and 1997 the correlation was only at a moderate level with a coefficient of determination of 0.10 .

6. In the strong La-Nina years 2008 and 2011 only at a moderate level with a coefficient of determination of 0.2 .

7. From this study it can be concluded that from the SOI variable there is a weak to moderate relationship to groundwater availability value especially in El-Nino and La-Nina year with storng phase.

\section{Acknowledgement}

The author would like to thank many parties who have provided information and support for the results of this research. Thanks to the Head of the Palembang Climatology Station, Head of the Section of the Palembang Climatology Station Observation, Head of the Data and Information Section of the Palembang Climatology Station, Staff of the Palembang Climatology Station, Sriwijaya Univeristy and various parties who cannot be mentioned one by one.

\section{References}

[1] U. Haryanto, "Analisis Klimatologi Indeks Osilasi Selatan (SOI) untuk Pendugaan Musim TigaBulan ke Depan Menggunakan Regresi Linier ", Jurnal Sains \& Teknologi Modifikasi Cuaca, vol. 3, no. 1, pp. 17 - 21, 2002.

[2] WMO, El Niño / Southern Oscillation. Geneva: World Meteorological Organization, 1997. 
[3] M. Syaifullah, "Kajian Sea Surface Temperature (SST), Southern Oscillation Index (SOI) dan Dipole Mode Pada Kegiatan Penerapan Teknologi Modifikasi Cuaca di Provinsi Riau dan Sumatera Barat Juli - Agustus 2009", Jurnal Sains \& Teknologi Modifikasi Cuaca, vol. 11, no. 1, p. $1,2010$.

[4] T. Putranto and K. Kusuma, "Permasalahan Air Tanah Pada Daerah Urban", Jurnal TEKNIK, vol. 30, no. 1, pp. 48 - 56, 2009.

[5] J. Monteith. "Evaporation and Environment ",19th Symposium of the Society for Experimental Biology, Cambridge : Cambridge Univ. Press, , pp. 205-234, 1965.

[6] C. Thornthwaite and J. Matter. Instruction and tables for computing potensial evapotranspiration and water balance. New Jersey : Drexel, Institute of Climatology, 1957.
[7]W. Hamon, "Estimationg Potential Evapotranspiration," B. S. thesis, Massachusetts Insitute of Technology, Dept. of Civil and Sanitary Enginering, 1960.

[8] Y. Jang, Y. Kim and S. Lee, "Hydraulic properties and leachate level analysis of Kimpo metropolitan landfill, Korea", Waste Management, vol. 22, no. 3, pp. 261-267, 2002.

[9] E. Soulis, J. Craig, V. Fortin and G. Liu, "A simple expression for the bulk field capacity of a sloping soil horizon", Hydrological Processes, vol. 25, no. 1, pp. 112-116, 2010.

[10]H. Pawitan and I. Lass. Keseimbangan Air Hidrologi di Indonesia Menurut Kabupaten (Hydrology Water Balance of Indonesia. Bogor: FMIPA IPB, 1996.

[11] J. Guilford. Fundamental Statistic in Psychology and Education. New York: McGraw-Hill Book Company, Inc, 1956. 